Vol. 1, No. 2, Desember 2021: h.120-137. DOI: 10.53088/jih.v1i2.111

E-ISSN: 2807-2995 https://journal.nurscienceinstitute.id/index.php/jih

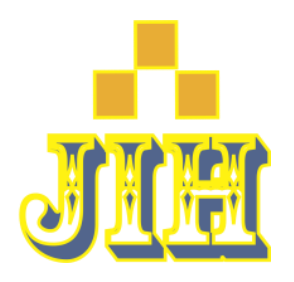

\title{
Perubahan Perilaku Masyarakat Petani Muslim Undaan Kudus terhadap Sistem Penanggalan Jawa Pranata Mangsa 2000-2018
}

\author{
Ahmad Musta'id \\ UIN Sunan Kalijaga Yogyakarta \\ ahmadmustaid@gmail.com
}

\begin{tabular}{|c|c|c|}
\hline Submited: & Revision Required: & Published: \\
7 Agustus 2021 & 09 Agustus 2021 & 23 Agustus 2021 \\
\hline
\end{tabular}

\begin{abstract}
This study discusses a socio-cultural history of Islam in a society regarding the reflection of the Javanese people's ability to read natural signs to determine the calculation of the seasons that will be used in farming, which is called Pranata Mangsa. The existence of the Pranata Mangsa Javanese calendar which later developed became a guideline in farming activities for Muslim farming communities in Undaan Kudus. However, if we look at several phenomena from the early 2000s AD to the present, especially regarding the seasons, of course there are many seasonal changes that occur on this Earth. The changing seasons on Earth occur due to various factors. This factor is due to the existence of several natural phenomena. This research uses historical methods and anthropological approaches. The anthropological approach can serve to study the socio-cultural background of past events, while history serves to study the cultural changes that occurred in the Muslim farming community of Undaan Kudus. This study shows that the socio-cultural conditions of the Muslim farming community are changing. The Muslim farming community of Undaan Kudus which was initially very thick with the guidelines of Pranata Mangsa with various religious ceremonies,
\end{abstract}


gradually underwent a change by following the existence of modernism due to difficulties in reading natural signs.

Keywords: calendar, change, pranata mangsa

\begin{abstract}
Abstrak
Penelitian ini membicarakan tentang sebuah sejarah sosial-budaya Islam suatu masyarakat perihal refleksi dari kemampuan masyarakat Jawa untuk membaca tanda-tanda alam untuk menentukan perhitungan musim yang akan digunakan dalam bercocok tanam yang dinamakan dengan Pranata Mangsa. Adanya Penanggalan Jawa Pranata Mangsa yang kemudian berkembang dijadikan pedoman dalam kegiatan bertani bagi masyarakat petani muslim yang ada di Undaan Kudus. Namun, apabila kita melihat beberapa fenomena di awal tahun $2000 \mathrm{M}$ hingga saat ini terutama berkaitan tentang musim, tentu banyak perubahan musim yang terjadi di muka Bumi ini. Berubahnya musim di muka Bumi ini terjadi karena berbagai faktor. Faktor tersebut ialah karena adanya beberapa fenomena alamiah. Peneletian ini menggunakan metode sejarah dan pendekatan antropologi. Pendekatan antropologi dapat berfungsi untuk mempelajari latar belakang sosial-budaya dari peristiwa-peristiwa masa lampau, sedangkan sejarah berfungsi untuk mempelajari perubahan-perubahan kebudayaan yang terjadi pada masyarakat petani muslim Undaan Kudus. Penelitian ini menunjukkan bahwa keadaan sosial budaya masyarakat petani muslim yang berubah. Masyarakat petani muslim Undaan Kudus yang awalnya sangat kental dengan pedoman Pranata Mangsa dengan berbagai upacara keagamaan, lambat laun mengalami perubahan dengan mengikuti adanya modernisme akibat kesusahan dalam mambaca tanda-tanda alam.
\end{abstract}

Kata Kunci: penanggalan, perubahan, pranata mangsa

\title{
PENDAHULUAN
}

Waktu merupakan suatu hal yang sangat berpengaruh bagi setiap kehidupan manusia. Dalam sistem peradaban kehidupan manusia, baik peradaban manusia kuno hingga peradaban modern, sebuah sistem pengorganisasian waktu secara terpadu yang disebut dengan penanggalan merupakan suatu hal yang menjadi sebuah kebutuhan (Bashori, 2013). Penentuan kalender berkaitan dengan peradaban 
manusia, karena hal itu digunakan dalam penentuan waktu berburu, bertani, berimigrasi, peribadatan, dan perayaan-perayaan (Darsono, 2010). Di Indonesia, khususnya di Jawa, masyarakat memiliki warisan agung dari nenek moyang yang berupa penanggalan Jawa yang disebut dengan Pranata Mangsa. Pranata Mangsa sesungguhnya sudah digunakan sejak lama oleh masyarakat Jawa (Bashori, 2013). Akan tetapi, Pranata Mangsa ini baru ditetapkan oleh Raja Pakubuwono VII dan dimulai sejak 1856 M. Setelah itu, Pranata Mangsa mulai banyak dianut oleh para petani di wilayah Mataram dan sekitar wilayah Jawa Tengah dalam melaksanakan bercocok tanam termasuk wilayah kabupaten Kudus (Achmad, 2016).

Sistem penanggalan Jawa Pranata Mangsa merupakan sebuah refleksi kemampuan dari masyarakat Jawa dalam membaca tandatanda alam untuk menentukan perhitungan musim yang akan digunakan dalam bercocok tanam (Rini Fidiyani dkk, 2011). Dengan adanya sistem Pranata Mangsa, masyarakat Jawa, terutama para kaum petani memiliki pedoman waktu yang jelas dan pasti dalam bercocok tanam, agar hasil yang diperoleh nantinya dapat memuaskan (Bashori, 2013).

Kecamatan Undaan merupakan salah satu kecamatan yang dikenal sebagai lumbung pangan kabupaten Kudus. Mayoritas penduduk di wilayah kecamatan Undaan beragama Islam dan berprofesi sebagai petani (Statistik, 2000). Melihat mayoritas penduduk berprofesi sebagai petani, masyarakat petani muslim kecamatan Undaan memiliki pedoman membaca tanda-tanda alam yang mana sebenarnya dalam membaca tanda-tanda alam merupakan salah satu perintah dari Allah Swt yang mereka lakukan dalam hal ini diimplementasikan pada kegiatan bercocok tanam, yakni dengan menggunakan sistem Pranata Mangsa. Namun, seiring adanya berbagai modernitas, khususnya mulai pada tahun 2000 sampai sekarang, penanggalan Jawa Pranata Mangsa kurang diperhatikan oleh para petani muslim Undaan Kudus dan para generasi penerusnya, sehingga eksistensi penanggalan Jawa Pranata Mangsa dalam keadaan pudar (Rini Budiharti dkk, 2010). Berdasarkan problematika tersebut, penulis bermaksud meneliti tentang beberapa perubahan perilaku masyarakat petani muslim Undaan Kudus dengan 
menggunakan batasan waktu. Batasan waktu mengenai penelitian dilakukan pada tahun 2000 mengingat sebagai dasar dalam penggunaan beberapa teknologi meodern dan tahun 2018 sebagai dasar beberapa sumber data telah menunjukkan adanya beberapa pengaruh fenomena alamiah, modernitas, perkembangan ilmu pengetahuan dan teknologi yang sangat signifikan. Pada penelitain ini, penulis mengkaji secara kompleks dengan menggunakan batasan dalam beberapa rumusan masalah sebagai berikut: bagaimana kondisi sosial-budaya masyarakat petani muslim Undaan Kudus, bagaimana sistem penanggalan Jawa Pranata Mangsa serta mengapa terjadi perubahan perilaku masyarakat petani muslim Undaan Kudus.

\section{TEORI DAN METODOLOGI}

Penelitian ini adalah penelitian sejarah sosial-budaya Islam, sehingga dengan melihat orientasi penelitian tersebut, maka untuk mengkaji objek kajian penelitian, penulis menggunakan alat bantu analisis dengan menggunakan pendekatan yang dalam hal ini penulis menggunakan pendekatan sejarah dan pendekatan antropologi. Antropologi sebagai ilmu yang mempelajari makhluk atau manusia merupakan suatu integrasi dari beberapa ilmu yang masing-masing mempelajari suatu komplek masalah-masalah khusus mengenai manusia (Yanasari, 2019).

Disiplin ilmu sejarah dan antropologi mempelajari manusia sebagai objek kajian yang mencakup pelbagai dimensi kehidupan. Jika disiplin ilmu sejarah membatasi diri dengan hanya menggambarkan suatu peristiwa sebagai proses di masa lampau dalam bentuk cerita, disini sejarah berbeda dengan antropologi. Kejadian yang terjadi secara "einmalig" (sekali terjadi) tidak masuk dalam bidang perhatian antropologi. Namun, apabila suatu penggambaran sejarah menampilkan suatu masyarakat di masa lampau, dengan pelbagai aspek kehidupan termasuk ekonomi, politik, religius, dan keseniannya, maka gambaran itu mencakup unsur-unsur kebudayaan masyarakat tersebut, sehingga disini ada tumpang-tindih antara bidang sejarah dan antropologi (Kartodirdjo, 1993)

Pendekatan antropologi dapat berfungsi untuk mempelajari latar belakang sosial-budaya dari peristiwa-peristiwa masa lampau, 
sedangkan sejarah berfungsi untuk mempelajari perubahan-perubahan kebudayaan. Sedangkan dalam metodologi antropologis khususnya dalam pengkajian penelitian ini, penulis menggunakan alat bantu analisis dengan menggunakan pendekatan fungsional dalam studi masyarakat, yakni pendeskripsian suatu kebudayaan didasarkan pada sekelompok manusia yang tinggal di suatu daerah sebagai entitas yang lengkap dan sistematis. Dimana dalam hal ini komunitas dapat dipandang sebagai suatu sistem ekologi, sistem sosial, sistem pandangan hidup, dan sistem penyesuaian kepribadian (Abdurrahman, 2011).

Selain pendekatan, untuk lebih mempermudah dan mengetahui lebih dalam kajian penelitian sejarah sistem penanggalan Jawa Pranata Mangsa pada kaum petani muslim, maka dibutuhkan adanya teori, yaitu fungsionalisme yang dikembangkan oleh Bronislaw Malinowski (1884-1942) yang membuka jalan bagi penelitian lapangan modern. la mengisolir diri bersama penduduk asli pulau Trobrian, arah timur laut Papua New Guinea untuk mempelajari cara hidup mereka dengan jalan melakukan observasi berperanserta (participant observation). la adalah seorang fungsionalis. Apa yang ia pahami dengan fungsionalis adalah gagasan bahwa masyarakat dilihat sebagai suatu totalitas fungsional, seluruh adat kebiasaan dan praktik harus dipahami dalam totalitas konteksnya dan dijelaskan dengan melihat fungsinya bagi anggota masyarakat tersebut. la mengasumsikan bahwa semua unsur kebudayaan merupakan bagian-bagian yang berguna bagi masyarakat dimana unsur-unsur tersebut terdapat. Dengan kata lain, pandangan fungsional atas kebudayaan menekankan bahwa setiap pola tingkah laku, setiap kepercayaan dan sikap yang merupakan bagian dari kebudayaan suatu masyarakat, memerankan fungsi dasar di dalam kebudayaan yang bersangkutan. Segala sesuatu yang dikerjakan oleh penduduk atau warga harus dijelaskan dengan melihat perannya saat itu, bahkan ada kebiasaan yang tampak sebagai sisa dari periode sebelumnya mesti memiliki satu fungsi, dan fungsi itu adalah penjelasan yang sesungguhnya atas keberadaan adat kebiasaan tersebut. Hal terpenting dalam teori ini adalah metode inovatif Malinowski, hidup bersama masyarakat yang sedang diteliti, ambil bagian dalam aktifitas sehari-hari, belajar 
berbicara dengan bahasa mereka tanpa bantuan seorang penerjemah dan merekam segala sesuatu. Metode ini kemudian disebut dengan observasi partisipan (Connolly, 2002).

Berdasarkan dari hasil penelusuran penulis, dari beberapa buku atau karya tulis hasil penelitian yang mempunyai relevansi dengan masalah Pranata Mangsa diantaranya sebagai berikut :

Penelitian yang dilakukan oleh Sarwanto, Rini Budiharti, Dyah Fitriana yang berjudul "Identifikasi Sains Asli (Indigenous Science) Sistem Pranata Mangsa Melalui Kajian Etnosains" yang mengkaji tentang identifikasi konten sains yang ada pada sistem Pranata Mangsa, dimana dalam penelitiannya dijelaskan bahwasanya semakin lamanya musim kemarau (kemarau panjang) yang diakibatkan oleh EI Nino telah menggeser Pranata Mangsa yang selama ini berlaku di Pulau Jawa. Sedangkan penelitian ini tidak membahas berkaitan dengan perubahan perilaku terhadap Pranata Mangsa.

Selanjutnya, penelitian yang dilakukan oleh Rini Fidiyani dan Ubaidillah Kamal "Penjabaran Hukum Alam Menurut Pikiran Orang Jawa Berdasarkan Pranata Mangsa" dengan menitikberatkan pada pembahasan Pranata Mangsa dalam perspektif filosofi orang Jawa terhadap pandangan hukum alam dengan penjabaran antropologi hukum.

Selanjutnya, tulisan dari Isniyatin Faizah dalam sebuah skripsinya dengan judul "Studi Komparatif Sistem Penanggalan Jawa Pranata Mangsa dan Sistem Penanggalan Syamsiah yang Berkaitan dengan Musim". Dalam skripsi Faizah, Penelitian hanya terfokus pada perbandingan antara penanggalan Jawa Pranata Mangsa dengan penanggalan Syamsiah yang berkaitan dengan sistem musim dengan melakukan studi kasus di Kabupaten Sukoharjo Surakarta. Dimana Faizah dalam kesimpulan skripsinya memberikan keterangan bahwa untuk awal musim hujan dan awal musim kemarau di Kabupaten Sukoharjo Surakarta menurut penanggalan Jawa Pranata Mangsa secara umum mundur atau lebih lambat dari perhitungan sistem tersebut. Hal ini bisa dilihat pada hasil perbandingan antara sistem Pranata Mangsa dan sistem prakiraan BMKG untuk penentuan awal musim kemarau di Kabupaten Sukoharjo Surakarta pada tahun 2009- 
2013, dimana hanya pada tahun 2011 perhitungan Pranata Mangsa mengalami kesamaan.

Kemudian, Ahmad Shilahuddin juga mengangkat sebuah tulisan skripsi yang terkait dengan Pranata Mangsa dengan judul "Analisis Sistem Pranoto Mongso Dalam Kitab Qamarussyamsi Adammakna Karya K.P.H Tjakraningrat". Dalam pembahasan tulisannya, Ahmad Shilahuddin membahas secara global tentang konsep Penanggalan Jawa Pranata Mangsa dalam Kitab Qamarussyamsi Adammakna Karya K.P.H Tjakraningrat.

Berikutnya juga ada sebuah penelitian dari Janatun Firdaus dalam bentuk skripsi dengan judul "Analisis Penangggalan Sunda dalam Tinjauan Astronomi". Sebenarnya penelitian Jannatun Firdaus ini mengkaji masalah tentang Kalender Sunda yang dikaji dalam sudut pandang Astronomis. Namun, ternyata Kalender Sunda menjadi sedemikian unik juga memiliki sebagian kemiripan dengan penanggalan Jawa Pranata Mangsa, diantaranya dalam hal penamaan bulan yang sama antara bulan ke-1 hingga bulan ke-10, yaitu 1) Kasa, 2) Karo, 3) Katiga, 4) Kapat, 5) Kalima, 6) Kanem, 7) Kapitu, 8) Kawalu, 9) Kasanga, 10) Kadasa. Sedangkan pada Kalender Sunda bulan 11) Hapitlemah, dan 12) Hapitkayu. Pada Kalender Jawa Pranata Mangsa bulan 11) Dhesta, dan 12) Saddha.

Berikutnya penelitian dari Nihayatul Minani dalam bentuk skripsi dengan judul "Penanggalan Jawa Pranata Mangsa Perspektif IImu Klimatologi Pada Saat Tahun Terjadinya El Nino dan La Nina : Implementasi dalam Penentuan Arah Kiblat". Penelitian Nihayatul Minani menjelaskan perbandingan unsur klimatologi menurut Pranata Mangsa dengan saat terjadinya El Nino dan La Nina di Kabupaten Sukoharjo, dimana pada saat mangsa tertentu besaran unsur klimatologis pada tahun terjadinya EI Nino maupun La Nina terkadang lebih tinggi atau lebih rendah dibandingkan dengan besaran nilai unsur klimatologis menurut Pranata Mangsa, tidak ada nilai pada mangsa tertentu yang tepat sama diantara ketiganya. Masa tanam padi dan palawija pada saat tahun terjadinya EI Nino dan La Nina adakalanya lebih cepat atau lebih lambat dari jadwal menurut penanggalan Jawa Pranata Mangsa. Selain itu, penelitian ini menjelaskan bahwa fenomena El Nino tidak begitu berpengaruh terhadap implementasi 
penentuan arah kiblat karena pada saat tahun terjadinya El Nino terdapat bulan kering yang aman untuk melakukan penentuan arah kiblat, bahkan terdapat dua Mangsa yang tidak terjadi hujan sama sekali. Berbeda dengan EI Nino, fenomena La Nina cukup berpengaruh terhadap implementasi penentuan arah kiblat, karena pada saat tahun terjadinya La Nina hujan terjadi sepanjang tahun sakalipun terdapat empat bulan kering, namun pelaksanaan penentuan arah kiblat tetap saja berkemungkinan mengalami hambatan dengan adanya mendung bahkan hujan.

Melihat dari beberapa hasil penelusuran penulis berkaitan dengan beberapa penelitian terdahulu, maka penelitian dengan fokus sejarah sosial budaya Islam dengan mengambil temporal waktu tentang perubahan perilaku petani muslim terhadap Pranata Mangsa belum dikaji secara lengkap. Maka dari itu, kajian penelitian berkaitan dengan perubahan perilaku petani muslim terhadap Pranata Mangsa dalam dirasa sangat penting untuk dikaji.

\section{PEMBAHASAN}

\section{Kondisi Masyarakat Undaan Kudus}

Jumlah penduduk Undaan tercatat 74.631 jiwa yang terdiri dari 36.996 penduduk laki-laki $(49,6 \%)$ dan 37.635 penduduk perempuan $(50,4 \%)$ (Kudus, 2014). Sebagian besar penduduk kecamatan Undaan menganut agama Islam dengan presentase 99,1 \% (Statistik, Kecamatan Undaan dalam Angka 2017, 2017). Mayoritas penduduk desa di wilayah kecamatan Undaan berprofesi sebagai petani. Pada dasarnya masyarakat petani muslim di kecamatan Undaan kabupaten Kudus dikenal sebagai masyarakat "petani naluri atau adat", sehingga sebagian besar masyarakat petani muslim Undaan memiliki naluri dengan melihat tanda-tanda alam dalam proses bercocok tanam. Sektor pertanian merupakan produk unggulan kecamatan Undaan, dimana hampir $81 \%$ wilayah kecamatan Undaan adalah area persawahan. Produk pertanian yang utama di kecamatan Undaan adalah padi, jagung, ubi kayu, kacang tanah, kedelai, dan kacang hijau. Oleh karena itu, kecamatan Undaan terkenal sebagai pusat pangan di kabupaten Kudus (Kudus, 2014). 


\section{Perkembangan Sistem Penanggalan Jawa Pranata Mangsa}

Berkaitan dengan hadirnya agama-agama baru di Jawa membawa berbagai macam produk budaya yang diadaptasi dari negeri asal agama-agama tersebut. Diantara produk budaya yang dibawa agamaagama tersebut adalah sistem kalender atau penanggalan. Kalender atau penanggalan merupakan sistem penjejak waktu dalam jangka Panjang (Raharto, 2013). Ditinjau dari perspektif waktu penggunaannya, penggunaan kalender di Jawa dibagi dalam dua periode, yaitu periode Jawa-Hindu dan periode Jawa-Islam (Darsono, 2010).

\section{Periode Jawa Hindu}

Sebelum Islam masuk ke pulau Jawa, agama Hindu sudah terlebih dahulu berkembang dan menjadi agama mayoritas bagi orang-orang Jawa. Pengaruh kebudayaan Hindu yang berasal dari tanah ini juga turut menularkan kebudayaan-kebudayaan dari negeri asalnya, salah satunya adalah dengan dikenalkannya sistem kalender di tanah Jawa. Kalender tersebut kemudian dikenal dengan nama kalender Saka. Penamaan kalender tersebut diambil dari nama Aji Saka, yaitu seorang raja keturunan dari raja Hindu di India .

\section{Periode Jawa Islam}

Pada awal abad ke XVII, dimana pada saat itu agama Islam sudah berkembang pesat di pulau Jawa, kalender Saka masih eksis digunakan dalam kehidupan sehari-hari oleh orang-orang Jawa termasuk juga digunakan oleh kerajaan-kerajaan, antara lain Demak, Banten, dan Mataram. Namun, disisi lain, kalender Hijriah juga digunakan secara bersamaan. Sampai pada tahun 1633 M, Sultan Agung Hanyokrokusuma yang saat itu menjadi penguasa kerajaan Mataram Islam menghapus penggunaan kalender Saka di tanah Jawa dan menggantikannya dengan kalender Jawa-Islam. Pemberlakuan kalender Jawa-Islam di Jawa merupakan sebuah proyek besar yang pada awalnya dilakukan oleh Sultan Agung Hanyokrokusuma sebagai 
usahanya untuk menyatukan pulau Jawa di bawah kekuasaannya (Darmawijaya, 2010).

Selain itu, ada beberapa alasan terkait dengan penetapan kalender Jawa Islam yang dilakukan oleh Sultan Agung. Pertama, mempertahankan kebudayaan asli Jawa dengan mewadahi Pawukon dan sebangsanya yang dilakukan dalam memperingati hari kelahiran orang Jawa, mengerti watak dasar manusia dan prediksi peruntungan menurut Primbon Jawa. Kedua, melestarikan kehidupan Hindu yang kaya akan kesusasteraan, kesenian, arsitektur candi dan agama, hal ini sangat penting karena kebudayaan Hindu telah berhasil menghiasi dan memperindah budaya Jawa selama berabad-abad sebelumnya. Ketiga, menyelaraskan kebudayaan Jawa dengan kebudayaan Arab. Sistem penanggalan Tahun Jawa yang serupa dengan penanggalan Hijriah atau Qamariah akan memudahkan masyarakat Islam di Jawa untuk menjalankan ibadahnya (Hambali, 2011).

Kalender Jawa Islam ini mempunyai fungsi lain yang tidak hanya sebagai penentu hari, tanggal, dan hari-hari keagamaan saja, akan tetapi juga menjadi dasar dan erat kaitannya dengan apa yang disebut dengan Petangan Jawi. Petangan Jawi ini merupakan perhitungan baik-buruk yang digambarkan dalam lambang dan watak suatu hari, tanggal, bulan, tahun dan lain-lain. Semua hal itu merupakan warisan asli leluhur Jawa yang dilestarikan dalam kearifan Sultan Agung dalam kalendernya. Selain memuat tentang perhitungan baik dan buruk yang dihubungkan dengan nasib seseorang, kalender Jawa ini mempunyai fungsi lain yaitu sebagai pedoman dalam kegiatan usaha tani maupun persiapan diri menghadapi bencana (kekeringan, wabah penyakit, serangan pengganggu tanaman, atau banjir) yang timbul waktu-waktu tertentu yang dikenal dengan sebutan mangsa, yang kemudian dikenal istilah Pranata Mangsa (Purwadi, 2006).

Pranata Mangsa merupakan cara tradisional masyarakat Jawa dalam memprediksi cuaca dan iklim yang sudah ada sejak dulu yang berdasar pada kejadian-kejadian alam, sehingga pengguna cara ini harus "cermat" (dalam istilah Jawa : titen) kapan musim tanam dan kapan musim panen. Penanggalan Jawa Pranata Mangsa dikenal baik di kalangan petani di Jawa terutama sebagai panduan dalam panduan bercocok tanam. Beberapa contohnya adalah memindahkan bibit padi 
paling baik dilakukan pada musim (mangsa) kelima. Untuk memanen padi paling baik dilakukan pada mangsa kedelapan. Sedangkan untuk menanam palawija dilakukan pada mangsa ketiga (Sitaningtyan, 2016).

Pranata Mangsa juga merupakan salah satu kearifan lokal masyarakat Jawa yang berkaitan dengan pengelolaan lahan pertanian. Penerapan Pranata Mangsa menunjukkan bahwa orang Jawa tidak akan pernah lepas dari lingkungan. Sejak zaman dahulu, orang Jawa telah memandang alam sebagai subjek, yang artinya mereka tunduk kepada alam (Anaziva, 2016).

Berdasarkan dalam konsep Pranata Mangsa, terdapat sebuah pertalian berbagai aspek secara komprehensif yaitu aspek-aspek yang bersifat kosmografis dan bioklimatologis yang mendasari kehidupan sosial-ekonomi dan sosial-budaya masyarakat petani di pedesaan. Pranata Mangsa mencerminkan ontologi menurut konsepsi Jawa serta alam pikiran petani Jawa yang dilukiskan dengan berbagai lambang dan watak-watak mangsa dalam peristilahan kosmologis yang mencerminkan harmoni antara manusia, kosmos, dan realitas (Bashori, 2013).

Sistem Pranata Mangsa juga merupakan suatu sistem warisan leluhur Jawa yang berusaha untuk memahami alam kanyatan dan kasunyatan. Kemampuan orang Jawa dalam membaca tanda-tanda jaman secara waskitha (ilmu dan pengetahuan) dan wicaksan (arif atau bijaksana, penuh pertimbangan moral) diwariskan secara turun temurun. Ramalan, petungan, dan keberuntungan nasib manusia mengacu pada perubahan musim, siklus alam, suatu hari dan sasmita ghaib. Sistem Pranata Mangsa bagi kaum petani muslim di kecamatan Undaan kabupaten Kudus digunakan untuk "niteni". Ilmu niteni yang dilakukan oleh nenek moyang terdahulu sehingga menghasilkan konsep yang dinamakan Pranata Mangsa ini merupakan suatu tindakan yang merupakan sebuah bentuk refleksi terhadap perintah Allah Swt. Hal ini menjadikan Pranata Mangsa sebagai bukti bahwa kaum petani muslim kecamatan Undaan kabupaten Kudus telah memenuhi seruan yang terkandung dalam al-Qur'an untuk membaca dan mempelajari ayat-ayat kauniyah yang berupa fenomena alam dan ciptaan Allah Swt. Pranata Mangsa terdiri atas 12 mangsa yang masing-masing memiliki indikator, dan indikator ini dapat dimanfaatkan 
untuk membuat perkiraan tentang permulaan musim hujan, permulaan musim kemarau, dan lain-lain. Pranata Mangsa meliputi pembagian musim (mangsa) dan jumlah hari, aktivitas (kegiatan) petani, ciri-ciri yang tampak (tanda-tanda alam) pada masing-masing mangsa (Hartono Kristoko dkk, 2012).

Masyarakat petani muslim kecamatan Undaan Kudus menggunakan pedoman konsep Pranata Mangsa dalam jadwal pemberlakuan sama seperti konsep yang utuh seperti dahulu yang saat ini terdapat dalam sebuah buku "Seri Lawasan : Pranata Mangsa" karya dari Sindhunata. Beberapa konsep tersebut antara lain:

1. Mangsa Kasa ( 22 Juni - 1 Agustus )

- Condro = sotya murca saka embanan

- Umur $=41$ hari

Mangsa Kasa merupakan mangsa yang jatuh pada mangsa katiga, atau masa terang yang biasanya kering. Mangsa ini ditandai dengan daun-daun yang berguguran. Pada mangsa ini petani membakar padi yang tersisa di sawah dan mulai menanam palawija (Sindhunata, 2011).

2. Mangsa Karo ( 2 Agustus - 24 Agustus )

- Condro = Bentalarengka

- Umur = 23 hari

Mangsa Karo merupakan mangsa bantala rengka, yaitu tanah retak dan berbongkah. Pada mangsa ini juga masuk dalam mangsa katiga dengan hawa menjadi panas. Pada mangsa ini Bumi terasa seperti merekah karena mangsa ini memasuki masa paceklik dengan ditandai mulai tumbuhnya palawija dan pohon randu serta mangga mulai bersemi (Sindhunata, 2011).

3. Mangsa Katelu ( 25 Agustus - 17 September )

- Condro = Suta manut ing bapa

- Umur = 24 hari

Memasuki mangsa katelu merupakan mangsa memuncaknya paceklik. Pada mangsa Katelu ini, tanah tidak dapat ditanami karena panasnya cuaca dan air yang minim. Pada musim ini para petani memanen palawija (Sindhunata, 2011). 
4. Mangsa Kapat ( 18 September - 12 Oktober)

- Condro = Waspa kumembeng jroning kalbu

- Umur = 25 hari

Mangsa Kapat termasuk dalam mangsa labuh, masa mulai berakhirnya kemarau. Pada mangsa ini sawah-sawah belum dapat ditanami padi sehingga petani menyiapkannya untuk penyemaian padi gogo (Sindhunata, 2011).

5. Mangsa Kalima (13 Oktober - 8 November)

- Condro = Pancuran emas sumawur ing jagad

- Umur = 27 hari

Mangsa Kalima masih termasuk dalam mangsa labuh. Pada mangsa ini para petani mulai mengolah sawah dan membuat irigasi, padi gogo juga mulai disebar (Sindhunata, 2011).

6. Mangsa Kanem ( 9 November - 21 Desember)

- Condro = Rasa mulyo kasucian

- Umur = 43 hari

Mangsa Kanem, mangsa yang masih dalam mangsa labuh. Pada mangsa ini, kondisi sawah-sawah kembali hijau dan air mulai mengalir jernih. Pada mangsa ini para petani juga mulai membajak area sawahnya (Sindhunata, 2011).

7. Mangsa Kapitu ( 22 Desember - 2 Februari )

- Condro = Wisa kentaring maruto

- Umur = 43 hari

Musim memasuki satuan besar mangsa rendheng, yang terdiri dari mangsa Kapitu, Kawolu, dan Kasanga. Pada mangsa ini, para petani pun mulai menyebar bibit di pawinihan atau tempat persemaian di tengah curah hujan yang tinggi, angin kencang, dan sungai-sungai yang meluap (Sindhunata, 2011).

8. Mangsa Kawolu (3 Februari - 28/29 Februari)

- Condro = Anjrah jroning kayun

- Umur = 26/27 hari

Pada mangsa ini, tanaman di sawah mulai menghijau, bahkan padi sudah meninggi (Sindhunata, 2011).

9. Mangsa Kasanga (1 Maret - 25 Maret)

- Condro = Wedaring wacara mulyo 
- Umur $=25$ hari

Pada mangsa ini ditandai oleh sebagian padi mulai berbunga dan sebagian lagi mulai berbuah (Sindhunata, 2011).

10. Mangsa Kasepuluh ( 26 Maret - 18 April )

- Condro = Gedhong minep jroning kalbu

- Umur = 24 hari

Alam memasuki mangsa terakhir dalam setahun, yaitu mangsa mareng, terdiri dari mangsa Kasepuluh, Dhesta, dan Sadha. Pada mangsa kasepuluh, padi mulai menguning, pada saat inilah saat yang sangat tepat bagi para petani untuk memanen padi gogo (Sindhunata, 2011).

11. Mangsa Dhesta ( 19 April - 11 Mei )

- Condro = Sotya sinara wedi

- Umur = 23 hari

Pada mangsa Dhesta, ditandai kondisi telur burung mulai menetas. Alam menunjukkan daya ciptanya lagi, walaupun musim kemarau makin dekat. Pada mangsa inilah para petani mulai panen padi (Sindhunata, 2011).

12. Mangsa Sadha ( $12 \mathrm{Mei}-21$ Juni)

- Condro = Tirta sah saking sasana

- Umur = 41 hari

Pada mangsa ini, orang jarang berkeringat karena udara yang dingin. Pada mangsa ini, para petani mulai menjemur padi dan memasukannya ke lumbung, hingga yang tersisa di sawah hanya batang padi kering. Kemudian mereka bersiap memasuki satuan mangsa katiga, mangsa yang mengawali peredaran siklus setiap tahunnya (Sindhunata, 2011).

\section{Alasan Perubahan Perilaku Sosial Budaya Masyarakat Petani Muslim Undaan Kudus}

Perubahan merupakan suatu keniscayaan. Setiap masyarakat pasti akan mengalami perubahan sosial karena pada dasarnya manusia memiliki sifat dinamis. Artinya masyarakat memiliki keinginan melakukan perubahan untuk memperbaiki kehidupannya. Oleh karena itu, setiap masyarakat akan mengalami perubahan sosial baik cepat maupun lambat. Perubahan sosial dalam masyarakat dapat diketahui 
dari perubahan pola perilaku, norma sosial, organisasi sosial, keadaan fisik suatu masyarakat, dan lapisan masyarakat. Manusia akan selalu melakukan perubahan dan mendapat pengaruh dari perubahan disekelilingnya. Menurut J.L. Gillin dan J.P. Gillin perubahan sosial merupakan suatu variasi cara hidup yang telah diterima, baik karena kondisi geografis, kebudayaan, komposisi penduduk, ideologi, maupun adanya penemuan baru dalam masyarakat (Wijayanti). Manusia juga memiliki sifat yang dinamis, kehidupannya juga dinamis. Artinya, manusia dan kehidupannya akan selalu mengalami perkembangan dan perubahan. Perubahan memiliki efek bagi pikiran manusia. Manusia yang takut berubah akan merasakan bahwa perubahan merupakan sebuah ancaman. Sebaliknya, bagi manusia yang berani dan percaya diri, perubahan justru menyenangkan dan memberi inspirasi (Wijayanti).

Seiring dengan adanya perubahan zaman yang ditandai dengan semakin majunya ilmu pengetahuan dan teknologi di bidang pertanian, khususnya mulai abad ke-20, para petani muslim Undaan Kudus mulai berkurang dalam penggunaan sistem Pranata Mangsa sebagai pedoman dalam bercocok tanam. Selain adanya perkembangan ilmu pengetahuan dan teknologi, adanya perubahan iklim secara global yang membuat perubahan musim menjadi tidak menentu dan munculnya beberapa fenomena alamiah seperti Dipole Mode fenomena El Nino yang memperpanjang musim kemarau dan La Nina yang memperpanjang musim hujan dan dipengaruhi oleh Sirkulasi Monsoon yang menimbulkan perbedaan iklim antara musim hujan dan musim kemarau serta adanya pengaruh fenomena regional seperti Inter Tropical Convergence Zone (ITCZ) yang merupakan daerah pertumbuhan awan dan kondisi suhu permukaan laut sekitar wilayah Indonesia juga sangat berpengaruh besar. Perubahan musim yang tidak menentu menyulitkan para petani muslim Undaan Kudus untuk membaca fenomena perubahan alam sebagai penanda perubahan musim (Semarang, 2018). Adanya beberapa faktor tersebut menjadi sebuah kelemahan sistem Penanggalan Jawa Pranata Mangsa. Terlebih di angka tahun 2016-2018, sumber data menunjukkan adanya ketidakstabilan dalam penentuan musim akibat ketidaksetabilan intensitas curah hujan. Hal ini membuat para petani kesusahan dalam 
menentukan musim. Sehingga para petani muslim Undaan Kudus yang awalnya sebagian besar dikenal sebagai "petani naluri atau adat" yang sangat kental dalam penggunaan perilaku nalurinya dengan melihat tanda-tanda alam yang dikonsepkan dengan sistem Pranata Mangsa dalam memenuhi seruan dalam al-Qur'an untuk membaca dan mempelajari ayat-ayat kauniyah yang berupa fenomena alam dan ciptaan Allah Swt kini eksistensinya semakin berkurang. Hal ini menjadi bukti bahwa masyarakat petani muslim Undaan Kudus mulai mengalami perubahan sosial-budanya dari yang awalnya sangat kental dengan corak atau ciri khas tradisionalnya menuju kearah perkembangan modernisme dan kemajuan zaman.

\section{KESIMPULAN}

Berdasarkan dari beberapa uraian diatas, kondisi sosial-budaya petani muslim Undaan Kudus menunjukkan keadaan sosial budaya yang berubah. Masyarakat petani muslim Undaan yang awalnya menunjukkan bahwa sebagai orang Jawa tidak akan pernah lepas dari lingkungan dan telah memandang alam sebagai subjek, yang artinya mereka tunduk kepada alam yang dikonsepkan dalam sistem Penanggalan Jawa Pranata Mangsa namun lambat laun mengalami perubahan.

Sistem Penanggalan Jawa Pranata Mangsa yang merupakan sebuah cara tradisional masyarakat petani muslim Undaan Kudus dalam memprediksi cuaca dan iklim yang sudah ada sejak dulu yang berdasar pada kejadian-kejadian alam kini eksistensinya semakin berkurang. Sehingga, dengan adanya kurangnya perhatian dari para generasi penerus dan petani muslim Undaan Kudus, maka eksistensi Pranata Mangsa semakin berkurang.

Perubahan perilaku masyarakat petani muslim Undaan terhadap kurangnya perhatian pada sistem penanggalan Jawa Pranata Mangsa diakibatkan oleh adanya beberapa faktor. Adanya pengaruh dari modernitas di abad ke-20 dan adanya berbagai fenomana alamiah seperti El Nino, La Nina, dan Sirkulasi Monsoon membuat para petani muslim Undaan Kudus mulai mengalami kesusahan dalam membaca tanda-tanda alam. Hal tersebut terlihat dari pola perilaku petani muslim Undaan Kudus yang awalnya sangat fanatik dengan corak tradisional, 
namun lambat laun kini mulai mengabaikan corak tradisional dan beralih mengikuti pola modernitas.

\section{REFERENCES}

Abdurrahman, D. (2011). Metodologi Penelitian Sejarah Islam. Yogyakarta: Penerbit Ombak.

Achmad, S. W. (2016). Babad Giyanti : Palihan Nagari dan Perjanjian Salatiga. Yogyakarta: Araska.

Anaziva, R. D. (2016). Pemanfaatan Sains Tradisional Jawa Sistem Pranotomongso melalui Kajian Etnosains sebagai Bahan Ajar Biologi. Jurnal Pendidikan Biologi Program Pascasarjana Universitas Negeri Yogyakarta, 834.

Bashori, M. H. (2013). Penanggalan Islam. Jakarta: PT Elex Media Komputindo.

Connolly, P. (2002). Aneka Pendekatan Studi Agama. Yogyakarta: LKiS.

Darmawijaya. (2010). Kesultanan Islam Nusantara. Jakarta: Pustaka al-kausar.

Darsono, R. (2010). Penanggalan Islam Tinjauan Sistem, Fiqih dan Hisab Penanggalan. Yogyakarta: Labda Press.

Hambali, S. (2011). Almanak Sepanjang Masa. Semarang: Program Pascasarjana IAIN Walisongo Semarang.

Hartono Kristoko dkk. (2012). Updated Pranata Mangsa : Recombination of Local Knowledge and Agro Meteorology using Fuzzy Logic for Determining Planting Pattern. UCSI International Jurnal of Computer Science Issues, 368.

Kartodirdjo, S. (1993). Pendekatan IImu Sosial dalam Metodologi Sejarah. Jakarta: Gramedia Pustaka Utama.

Kudus, P. k. (2014). Data Base Ketahanan Pangan Kabupaten Kudus.

Kudus: Pemerintah Kabupaten Kudus Kantor Ketahanan Pangan.

Purwadi. (2006). Petungan Jawa: Menentukan Hari Baik dalam Kalender Jawa. Yogyakarta: Pinus Book Publisher.

Raharto, M. (2013). AS 3006 Dasar-dasar Sistem Kalender Bulan dan Kalender Matahari. Bandung: Program Studi Astronomi Institut Teknologi Bandung. 
Rini Budiharti dkk. (2010). Identifikasi Sains Asli (Indeginous Science) Sistem Pranata Mangsa Melalui Kajian Etnosains. Surakarta: Fakultas Keguruan dan IImu Pendidikan Universitas Sebelas Maret.

Rini Fidiyani dkk. ( 2011). Cara Berhukum Orang Banyumas dalam Pengelolaan Lahan Pertanian Studi Berdasarkan Perspektif Antropologi Hukum. Semarang: Fakultas Hukum Universitas Negeri Semarang.

Semarang, B. M. (2018). Prakiraan musim kemarau 2018 Jawa

Tengah. In B. M. Semarang, Prakiraan musim kemarau 2018 Jawa Tengah (p. 3). Semarang: Badan Meteorologi Klimatologi dan Geofisika Stasiun Klimatologi Semarang .

Sindhunata. (2011). Seri Lawasan : Pranata Mangsa. Jakarta: Kepustakaan Populer Gramedia.

Sitaningtyan, H. A. (2016). Nilai Luhur Pranata Mangsa dalam Sistem Pertanian Modern. Jurnal Hijau Cendekia, 30.

Statistik, B. P. (2000). Posisi Kabupaten Kudus di Peta Jawa Tengah. Kudus: Badan Pusat Statistik bekerjasama dengan Badan Koordinasi Perencanaan Pembangunan Daerah Kabupaten Kudus.

Statistik, B. P. (2017). Kecamatan Undaan dalam Angka 2017. Kudus: Badan Pusat Statistik Kabupaten Kudus.

Wijayanti, F. (n.d.). Mengenal Perubahan Sosial. Klaten: Cempaka Putih.

Yanasari, P. (2019). Pendekatan Antropologi dalam Penelitian Agama bagi Sosial Worker. Jurnal Pengembangan Masyarakat Islam, 228. 